\title{
Riders on the storm: loggerhead sea turtles detect and respond to a major hurricane in the Northwest Atlantic Ocean
}

\author{
Leah M. Crowe ${ }^{1 *}$, Joshua M. Hatch², Samir H. Patel ${ }^{3}$, Ronald J. Smolowitz ${ }^{3}$ and Heather L. Haas²
}

\begin{abstract}
Background: Extreme weather events, including hurricanes, have considerable biological, ecological, and anthropogenic impacts. Hurricane Irene caused substantial economic damage when it hit the Mid-Atlantic Bight (MAB) off of the eastern United States in August of 2011. The MAB is highly stratified during the summer when a strong thermocline separates warm, surface water from deep, cold water, and this oceanographic phenomenon makes modeling hurricane strength difficult. Loggerhead sea turtles (Caretta caretta) forage in the MAB primarily during the stratified season and their dive behavior to the bottom allows them to experience the oceanographic conditions of the entire water column.
\end{abstract}

Methods: In this study, we analyzed the movements and dive behavior of juvenile and adult-sized loggerhead sea turtles $(n=18)$ that were foraging in the MAB as Hurricane Irene moved through the region. The satellite tags deployed on these turtles transmitted location data and dive behavior as well as sea surface temperature (SST) and temperature-depth profiles during this time.

Results: Behavioral and environmental shifts were observed during and after the hurricane compared to conditions before the storm. During the hurricane, most of the turtles $(n=15)$ moved north of their pre-storm foraging grounds. Following the storm, some turtles left their established foraging sites $(n=8)$ moving south by 7.3-135.0 $\mathrm{km}$, and for the others that remained $(n=10), 12 \%$ of the observed dives were longer $(0.54-1.11 \mathrm{~h})$ than dives observed before the storm. The in situ data collected by the turtle-borne tags captured the cooling of the SST (Mean difference $=4.47^{\circ} \mathrm{C}$ ) and the deepening of the thermocline relative to the pre-storm conditions.

Conclusions: Some of the loggerhead behavior observed relative to a passing hurricane differed from the regular pattern of seasonal movement expected for turtles that forage in the MAB. These data documented the shifts in sea turtle behavior and distribution during an ecosystem-level perturbation and the recorded in situ data demonstrated that loggerheads observe environmental changes to the entire water column, including during extreme weather events.

Keywords: Satellite telemetry, Temperature, Behavioral response, Dive behavior, Cold pool, Mid-Atlantic bight, Extreme weather event

\footnotetext{
* Correspondence: leah.crowe@noaa.gov

'Integrated Statistics under contract to the Northeast Fisheries Science

Center, National Marine Fisheries Service, National Oceanic and Atmospheric

Administration, 166 Water Street, Woods Hole, MA 02543, USA

Full list of author information is available at the end of the article
}

(c) The Author(s). 2020 Open Access This article is licensed under a Creative Commons Attribution 4.0 International License, which permits use, sharing, adaptation, distribution and reproduction in any medium or format, as long as you give appropriate credit to the original author(s) and the source, provide a link to the Creative Commons licence, and indicate if changes were made. The images or other third party material in this article are included in the article's Creative Commons licence, unless indicated otherwise in a credit line to the material. If material is not included in the article's Creative Commons licence and your intended use is not permitted by statutory regulation or exceeds the permitted use, you will need to obtain permission directly from the copyright holder. To view a copy of this licence, visit http://creativecommons.org/licenses/by/4.0/ The Creative Commons Public Domain Dedication waiver (http://creativecommons.org/publicdomain/zero/1.0/) applies to the data made available in this article, unless otherwise stated in a credit line to the data. 


\section{Background}

Extreme weather events, including hurricanes, have considerable biological, ecological, and anthropogenic impacts $[1,2]$, and the risk of loss increases as more people and resources interact with these disasters [2]. Hurricanes occur seasonally within each ocean basin, and have become more intense overtime, with this trend expected to continue [3]. Hurricane Irene hit the MidAtlantic Bight (MAB) of the United States' eastern seaboard in August 2011, causing 49 human deaths and cost an estimated $\$ 15.8$ billion (USD) in damages, mostly because of widespread flooding [4].

During the Atlantic hurricane season, the oceanography in the MAB is dynamic [5] and difficult to model [6] because a Cold Pool forms beneath a warm, surface layer [7-9]. Hurricane Irene was preempted by a $6^{\circ}-$ $11^{\circ} \mathrm{C}$ decrease in sea surface temperature (SST; i.e. ahead-of-eye cooling) and a deepening of the thermocline by more than $15 \mathrm{~m}$ [10], primarily due to hurricane forced vertical mixing which was not accurately accounted for in hurricane modeling $[10,11]$. The forecast for Hurricane Irene anticipated higher wind speeds that would have kept it along its projected path, but instead, the cooled surface waters decreased the strength of the storm before it made landfall, causing the storm to stall in areas that were unprepared [11]. Although the forecast models for Irene did not account for ahead-ofeye cooling, this phenomenon has occurred for all tropical cyclones that have interacted with the stratified conditions in the MAB since 1985 [10].

In addition to the impacts on the oceanography and human population, tropical storms and hurricanes can cause changes in the behavior of marine species. American lobsters (Homarus americanus) moved out of estuarine waters and into coastal waters during the passing of Hurricane Bob [12]. Sea snakes (Laticauda spp.) and juvenile blacktip sharks (Carcharhinus limbatus) moved into deeper waters as hurricanes and tropical storms caused barometric pressure to drop [13, 14]. Several shark species were temporarily displaced from study areas during the landfall of tropical storms [15], and increased emigration and daily movement rates of gray triggerfish (Balistes capriscus) were highly correlated with wave orbital velocity during the passing of two hurricanes [16]. Spotted seatrout (Cynoscion nebulosus) spawning was potentially delayed because of decreased water temperature due to a hurricane [17]. Finally, Eastern brown pelicans (Pelecanus occidentalis carolinensis) were observed sheltering in coastal regions during hurricanes to possibly allow for protection and rest [18].

There are few examples of sea turtle interactions with large storm events. Both a tagged loggerhead (Caretta caretta) and hawksbill (Eretmochelys imbricata) nesting female became more active when overlapping with extreme storms [19, 20]. Early tagging efforts of loggerhead sea turtles revealed some interaction between storms and two nesting females, but the data transmissions were thought to have been negatively impacted by the weather [21]. Adult loggerheads may have left their breeding areas in response to decreasing barometric pressure, a possible signal of worsening conditions [22]. Juvenile hawksbill turtles moved to deeper waters during two consecutive intense hurricane events in the Caribbean [23]. Modeling studies show that hurricanes can disrupt the migratory routes of younger sea turtles, potentially pushing them into unsuitable habitats $[24,25]$.

Foraging juvenile and adult loggerheads occur along the shelf in the MAB between May and September [26], overlapping substantially with the Atlantic hurricane season (June - November) [27] and the period when the Cold Pool is present (approximately May - October) [7] The oceanography of the MAB is likely to play an important role in hurricane behavior and disaster preparation in the future, and this has encouraged the use of gliders to collect in situ data as storms work their way up the Northwest Atlantic Ocean [9]. Loggerhead sea turtle morphology and foraging behavior make them good observers of oceanographic variables throughout the entire water column where they forage $[8,28]$, and the data derived from turtle-borne data loggers are currently an under-utilized resource that has the potential to improve forecasting models [29].

In this study, we analyzed loggerhead sea turtle behavior in the MAB and the environmental conditions observed from turtle-borne satellite tags in relation to Hurricane Irene. We determined that as the storm passed, the tagged turtles altered their dive behavior and movement patterns. These observed changes in behavior can provide insight into turtle reactions to other perturbations. The turtle-borne tags also recorded the environmental changes to the water column as the hurricane passed through the MAB, highlighting these data as a valid resource for weather forecasting models alongside other in situ data sources.

\section{Methods}

Loggerhead sea turtles were captured in early June and late July 2011 in the MAB with a large dip net. Netted turtles were transferred to a chartered commercial fishing vessel for sampling and tag attachment. Turtles were measured and weighed in compliance with the United States Endangered Species Act permitting requirements.

Satellite relay data loggers from the Sea Mammal Research Unit at the University of St. Andrews were attached to the carapace with a two-part epoxy. Tag parameterization was designed to allow for a lifespan achieving approximately 13 months [8]. For full details on handling and capture protocols as well as the 
parameterization of the tags used in this study, see Patel et al. [8]. A random sample of temperature-depth and dive data were transmitted [30], and recorded dives began when the tag was at or below $1.5 \mathrm{~m}$ depth for at least $20 \mathrm{~s}$ until it was dry or above $1.5 \mathrm{~m}$ depth. Tags were programmed to include both Fastloc-GPS and Argos locations for approximately the first three months of deployment, and Argos throughout the lifespan of the tag.

Location data from Argos and Fastloc-GPS data were filtered and combined into a single dataset. Only location quality classes 1-3 were retained for Argos positions, and Fastloc-GPS data were filtered for locations that were obtained using five or more satellites [31] where the residuals were greater than 0 and less than 25 . These location data were combined and a speed filter with a maximum rate of $10 \mathrm{~km} \mathrm{~h}^{-1}$ was applied to all location data [32]. Locations were mapped to ensure the lower resolution Argos locations fell within the path of the higher resolution Fastloc-GPS positions, and any visually erroneous points were excluded [33]. Data were compiled and analyzed using R 3.5.1 [34] and the dplyr [35], geosphere [36], lubridate [37], and plyr [38] $\mathrm{R}$ packages.

Hurricane Irene first formed on 21 August 2011 and was absorbed on 30 August 2011 [4]. Using the best track from the National Hurricane Center [39], the storm's position at each location of a tagged turtle was determined using linear interpolation according to the following:

$$
\tilde{x}, \tilde{y}=(1-\alpha)\left(x_{1}, y_{1}\right)+\alpha\left(x_{2}, y_{2}\right)
$$

where $(\tilde{x}, \tilde{y})$ is the interpolated storm location, $\left(x_{1}, y_{1}\right)$ is the beginning location of the storm, $\left(x_{2}, y_{2}\right)$ is the ending location of the storm, and $\alpha$ is the proportion of regular interval time between the timestamp of $\left(x_{1}, y_{1}\right)$ and the timestamp associated with the tagged turtle's location. The shortest distance along an ellipsoid between the tagged turtle and the interpolated track of Hurricane Irene was then calculated.

Data derived from turtle-borne tags that were within $100 \mathrm{~km}$ of Hurricane Irene's path at their closest point $\left(T_{0}\right)$ were included in this analysis. This distance ensured the inclusion of shelf-foraging turtles that were within the scope of the hurricane (approximately $180 \mathrm{~km}$ wide) as it passed through the MAB $[4,39]$. Location data, temperature-depth profiles, and dive data two weeks before and after $T_{O}$ were compiled to obtain pre- and poststorm conditions and behaviors. These data were divided into five phases: Before, Approach, During, Departure, and After where the Approach and Departure phases provided 1.5 day buffers around the one day During period to distinguish clear 12 day Before and After phases
(Fig. 1a). Because each turtle had a unique $T_{0}$ and each tag transmitted at different times, the hurricane phases covered slightly different time periods for each turtle (Fig. 1b).

\section{Behavioral data}

The pre-storm foraging range for each turtle was calculated as the latitudinal range between the 5th and 95th percentile of the latitudinal extent for the turtle's movements three to six weeks prior to $T_{0}$. There was less focus on longitudinal movements as loggerhead sea turtles within the region typically remain resident during the foraging season and take seasonal long-distance latitudinal migrations when arriving and leaving the MAB [26]. Box plots of turtle latitude were calculated for the Before, During, and After phases to assess the extent of latitudinal movement. Turtle movements were characterized by analyzing the interquartile range (the middle $50 \%$ of the distribution) of latitudinal movements within the hurricane phases relative to the foraging range-if these overlapped, a turtle was considered to have remained in its foraging range.

Dive behaviors were assessed by analyzing daytime (0600-2000 EDT) dive duration and maximum dive depth for individuals that remained in their foraging ranges in order to investigate dive behavior relative to local changes in the habitat. Daytime diving was specifically chosen because changes to dive behavior could substantially impact the availability of turtles at the surface during line-transect surveys, and subsequent abundance estimates [40]. Dive duration relative to maximum dive depth was analyzed to better understand the composition of the type of dive behavior exhibited in each phase. To compare dive behavior relative to the hurricane, dive duration and maximum dive depth data were pooled and summarized for these turtles in the Before and After phases.

\section{Environmental data}

Turtles that remained in their foraging ranges along a similar latitudinal range were considered the best observers of the hurricane, and, therefore, SST data and temperature-depth profiles collected from the turtleborne tags of these individuals were analyzed. Data collected nearshore $(<5 \mathrm{~km})$ were excluded to ensure the comparison of temperatures was only across shelf waters and not from shallow, warmer regions. SST values were collected at $2.0 \mathrm{~m}$ depth and data collected from all turtle-borne tags were compiled together to gain a perspective on the conditions the turtles were experiencing throughout the passage of Hurricane Irene. SST data were pooled and summarized for these turtles in the Before and After phases to further compare these changes. Full water column 


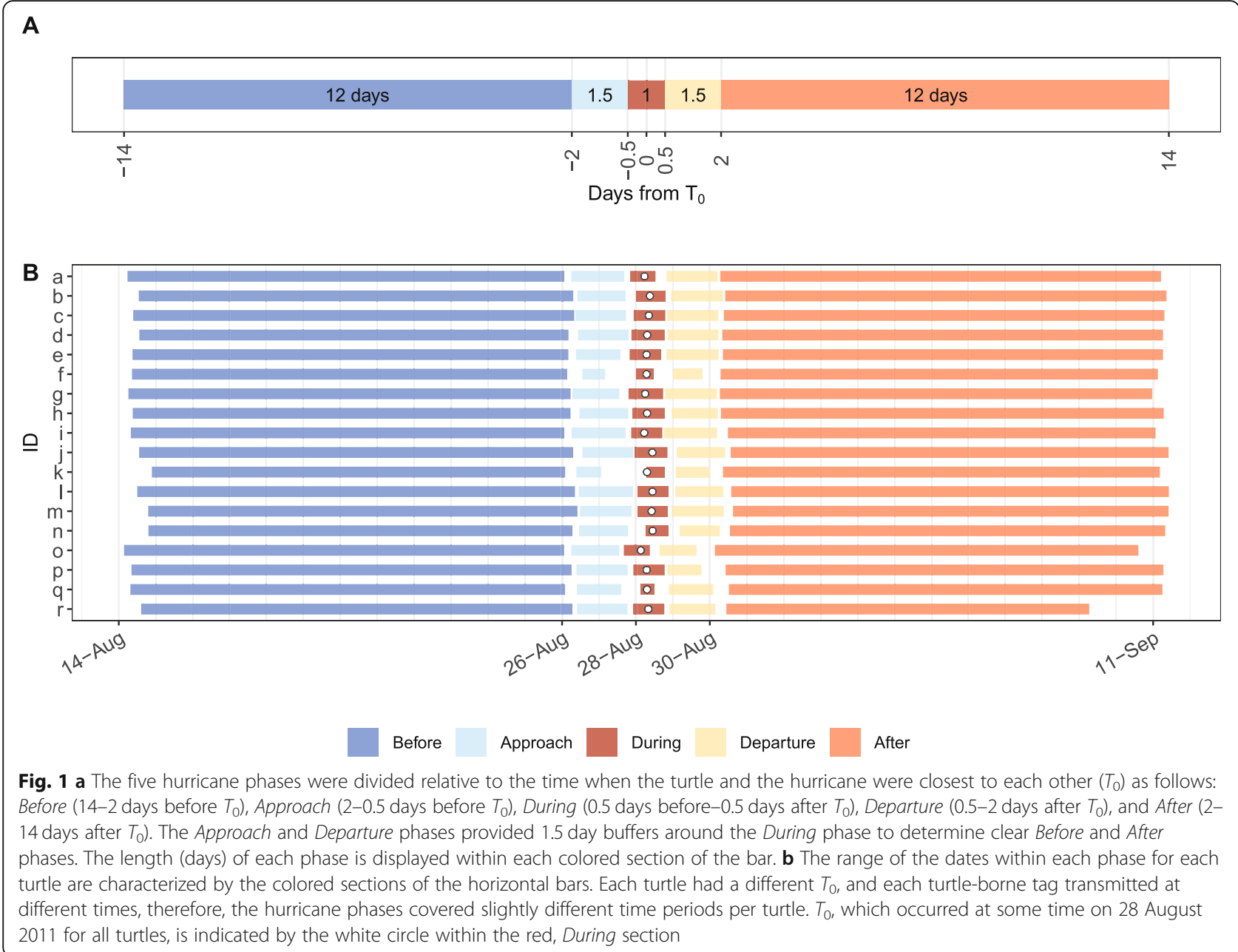

profiles were analyzed relative to each phase for each turtle to understand how the local water column may have been affected by the hurricane. Temperaturedepth profiles reaching within 15\% of ETOPO1 Ice Surface Global Relief Model [41] bathymetry were considered full water column profiles as described in Patel et al. [8]. Bathymetry was analyzed using the raster [42] and rgdal [43] $\mathrm{R}$ packages.

Turtle-borne tag locations and the hurricane's path were plotted using ArcGIS 10 [44] (Fig. 2a, b). The National Oceanic and Atmospheric Administration's National Data Buoy Center Station 44009 is positioned at $38.457^{\circ} \mathrm{N}, 074.702^{\circ} \mathrm{W}$ [45], halfway north to south between the turtles' extent. Due to its location and availability of data, this buoy was identified as the best source of traditional in situ weather data (barometric pressure, SST, wave height, and wind speed) for this region during Hurricane Irene (Fig. 2c).

Figures 1, 2c, 3, 4 and 5 were created using the ggplot2 [46] and ggpubr [47] R packages.

\section{Results}

Eighteen turtles were within $9.4-80.1 \mathrm{~km}$ of the eye of Irene at their closest points (Fig. 2a). Their straight carapace length (SCL), measured from nuchal notch to posterior marginal tip, ranged from 58.1 to $87.0 \mathrm{~cm}(n=17$, Mean $=73.0 \mathrm{~cm}$; Table 1). Six turtles $(e, g, h, m, p$, and $r)$ measured a SCL greater than $75 \mathrm{~cm}$, which was consistent with adult size according to Avens et al. [48]. Additionally, the curved carapace lengths measured from nuchal notch to posterior marginal tip $(n=18$, Mean $=$ $78.9 \mathrm{~cm}$ ) were used to identify the life stage corresponding to potential reproductive output according to Murray [49]. Six classifications are within this scheme ranging from Stage I to Stage V (adult)-Stage IV is divided into two categories, IVa and IVb, where Stage IVb has a wide range of reproductive potential [49]. Turtles in this study represented middle and later juvenile Stages III $(n=7)$, IVa $(n=7)$, and IVb $(n=4)$ (Table 1$)$.

The turtles were closest to Hurricane Irene's path $\left(T_{0}\right)$ on 28 August 2011 for all individuals when the severity of the storm ranged between a hurricane and a tropical 


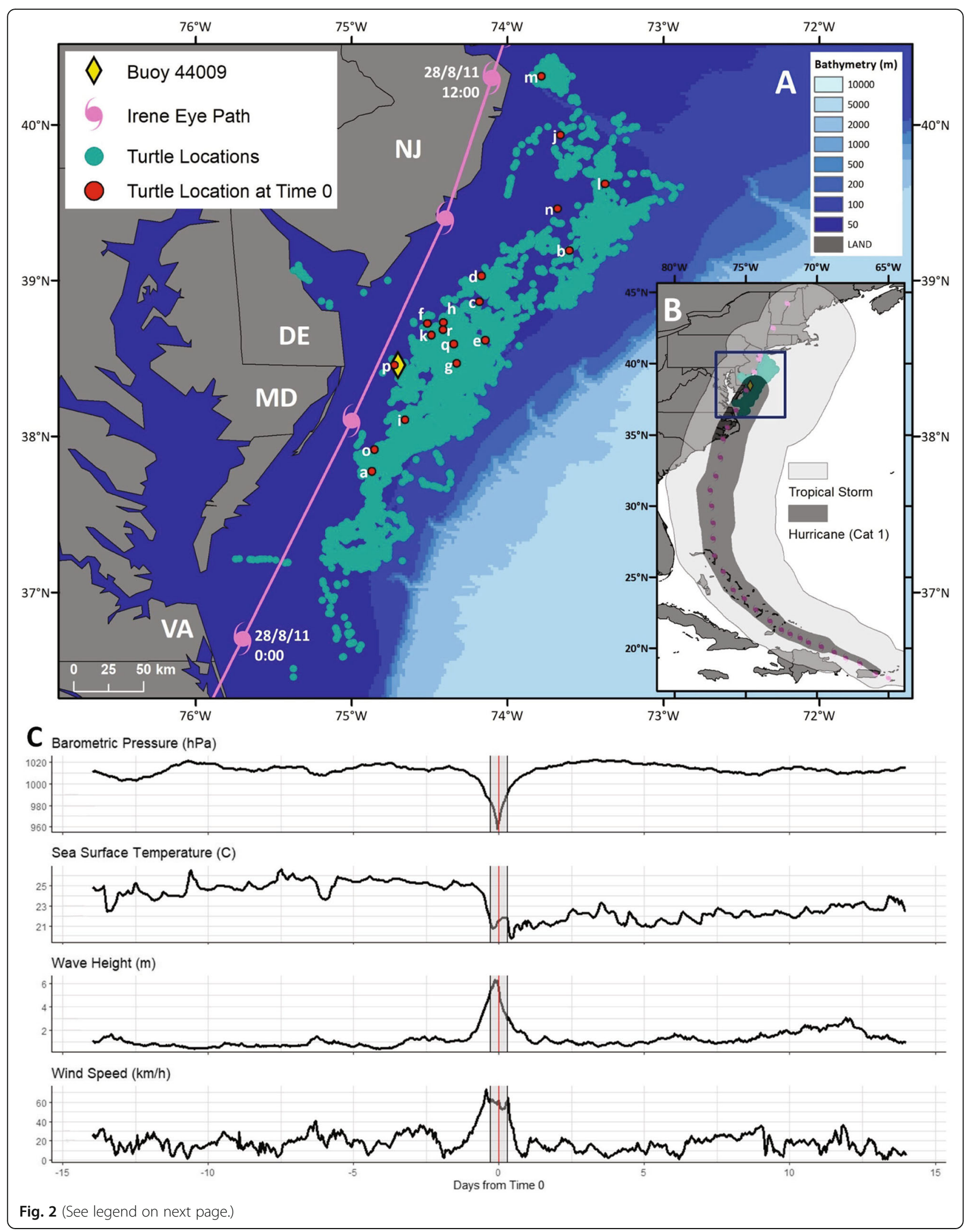


(See figure on previous page.)

Fig. 2 All locations transmitted from tagged turtles between 14 August and 11 September 2011 (green circles), the track of Hurricane Irene (pink symbols and lines, UTC) [39], and the environmental conditions two weeks before and after the hurricane recorded by buoy 44009 (yellow diamond) [45]. a The position where the hurricane and each turtle were closest to each other ( $\left.T_{0}\right)$ occurred on 28 August 2011 for all turtles and are indicated by the red circles. Buoy 44009 was close to the hurricane path and approximately in the middle of the turtle positions within this time period. b The inset map, denoted by the blue square, illustrates the wind speeds associated with Hurricane Irene. The dark grey indicates Category 1 hurricane strength $\left(119-153 \mathrm{~km} \mathrm{~h}^{-1}\right)$, and the light grey indicates tropical storm strength $\left(63-119 \mathrm{~km} \mathrm{~h}^{-1}\right)$. c Barometric pressure, sea surface temperature, wave height, and wind speed data gathered by buoy 44009 . The red vertical line denotes $T_{0}$, the grey shaded area bordered by the grey vertical lines denotes the 0.5 day period on either side of $T_{0}$ spanning the time frame of the During phase

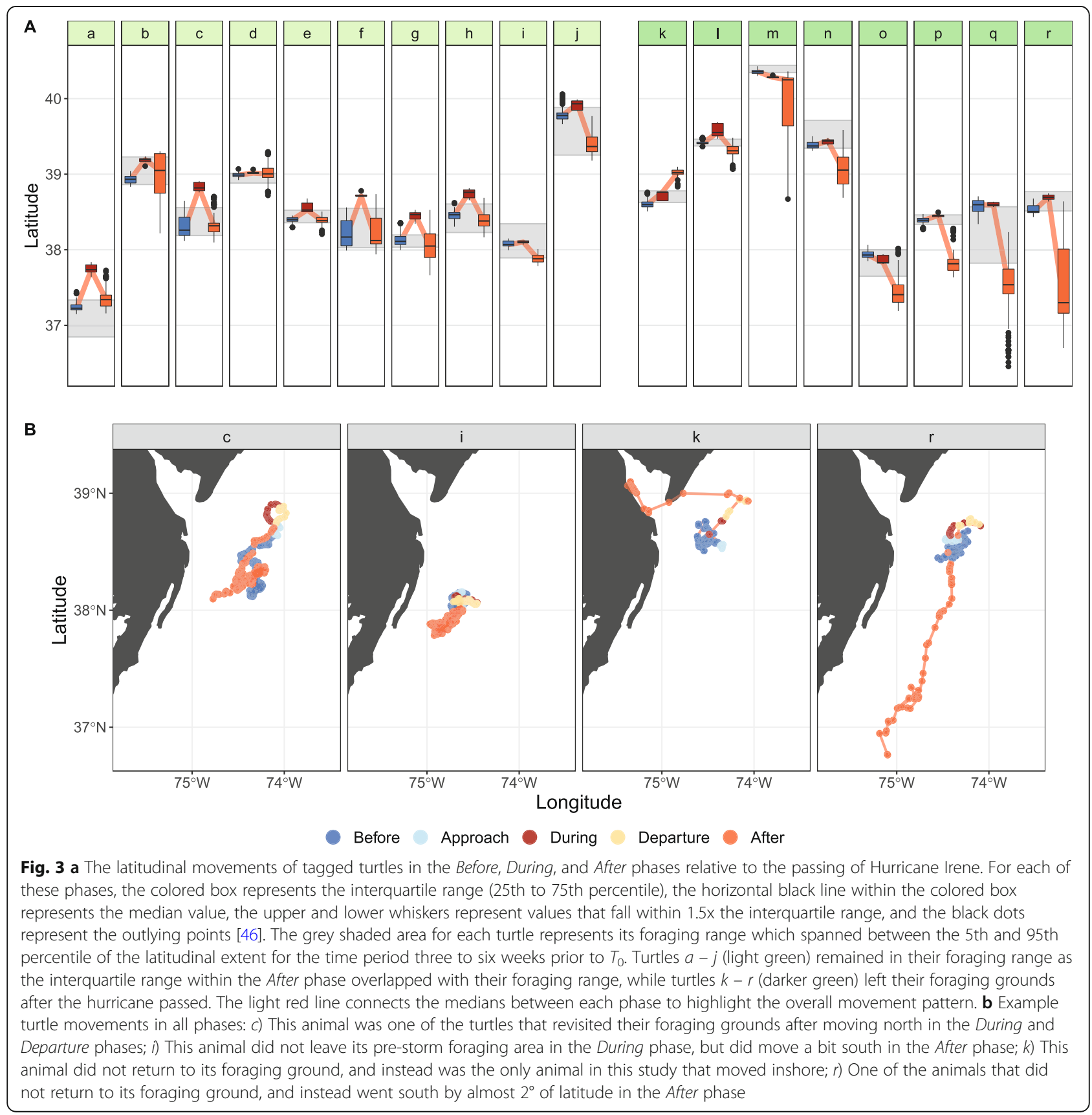




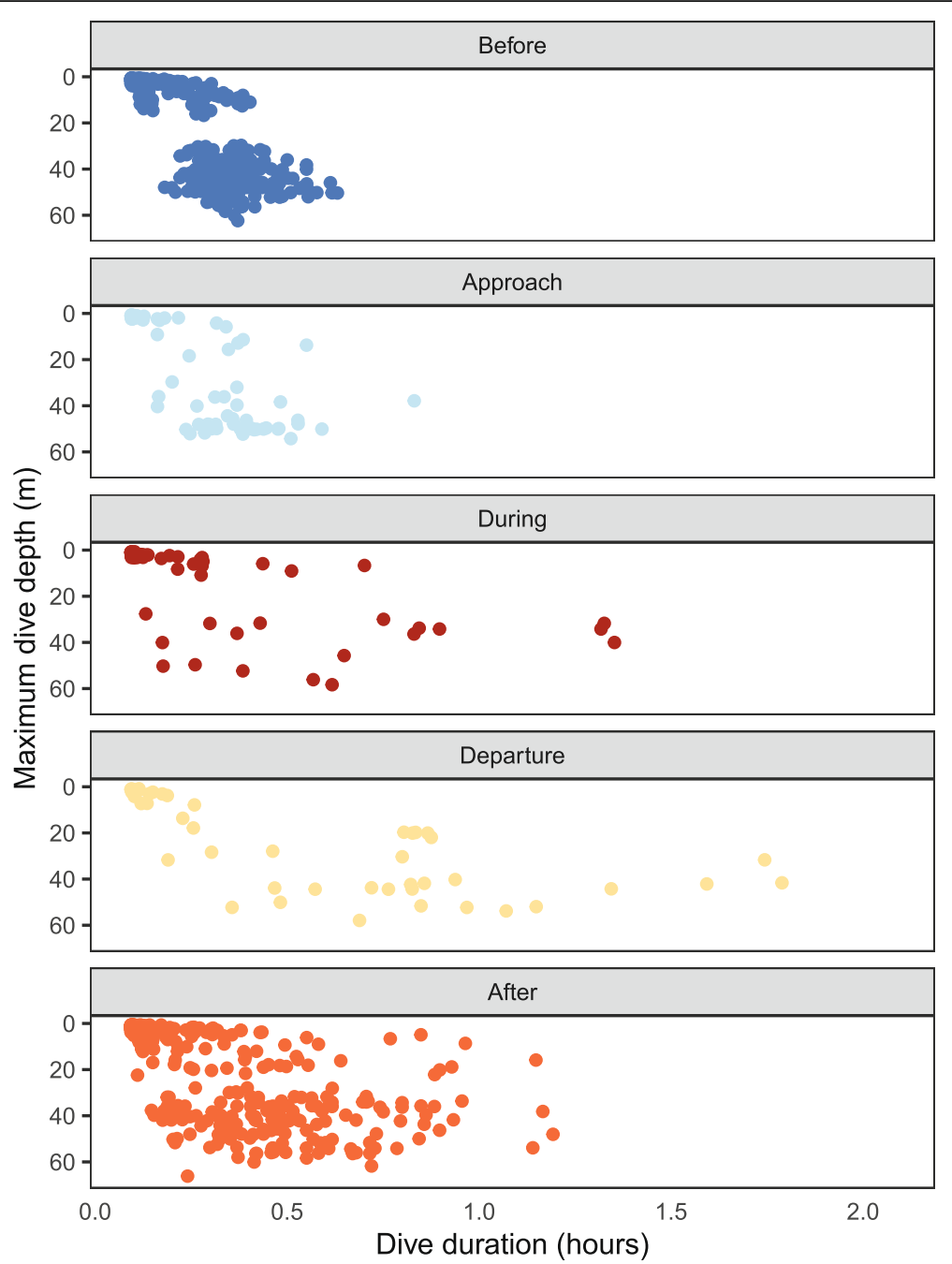

Fig. 4 Dive duration (hours) relative to the maximum dive depth $(m)$ throughout all phases for turtles that remained in their foraging grounds after Hurricane Irene passed $(a-j)$

storm. Within the five phases defined here (Before, Approach, During, Departure, and After), 5573 positions were transmitted from all turtle-borne tags between 14 August 2011 and 11 September 2011. Fastloc-GPS transmissions were received throughout the study period, and similar numbers of positions came from each source in the Before and After phases (ARGOS: Before $=720$, After $=698 ;$ Fastloc-GPS: Before $=1782$, After $=1617$; Supplementary Fig. 1A, Additional file 1). Of the 108 turtle-phase combinations (Supplementary Fig. 1B, Additional file 1 ), there were only six instances where more locations came from Argos than Fastloc-GPS $(k$ and $r$ in the Before, $a$ and $k$ in the Approach, and $d$ and $k$ in the During phases), and there were six cases where there was only Fastloc-GPS data. An additional interactive map can be used to further investigate the tracks, including the location source, for the turtles throughout this study period [see Additional file 2].

\section{Behavioral data}

Turtle pre-storm foraging areas occurred between $36.80^{\circ} \mathrm{N}$ and $40.47^{\circ} \mathrm{N}$ and were calculated from 6708 positions. This period occurred between 17 July 2011 and 14 August 2011 for all turtles except turtle $l$ where the included data began the day after it was tagged, 27 July 2011. The latitudinal extent of each area varied amongst individuals and ranged between 9.7 and $82.7 \mathrm{~km}$ (Fig. 3a).

Turtle residency Before the hurricane was primarily consistent with each turtle's pre-storm foraging area, but movement out of the foraging area was observed within the During and After phases of the hurricane. In the During phase, all but three of the turtles $(m, o$, and $q$ ) moved north, and about two thirds of the turtles $(a, c, d$, $e, f, g, h, j, l$, and $q$ ) had interquartile ranges north of their foraging areas-one turtle $(m)$ had an interquartile range south of its foraging area. Turtles moved 0.3 

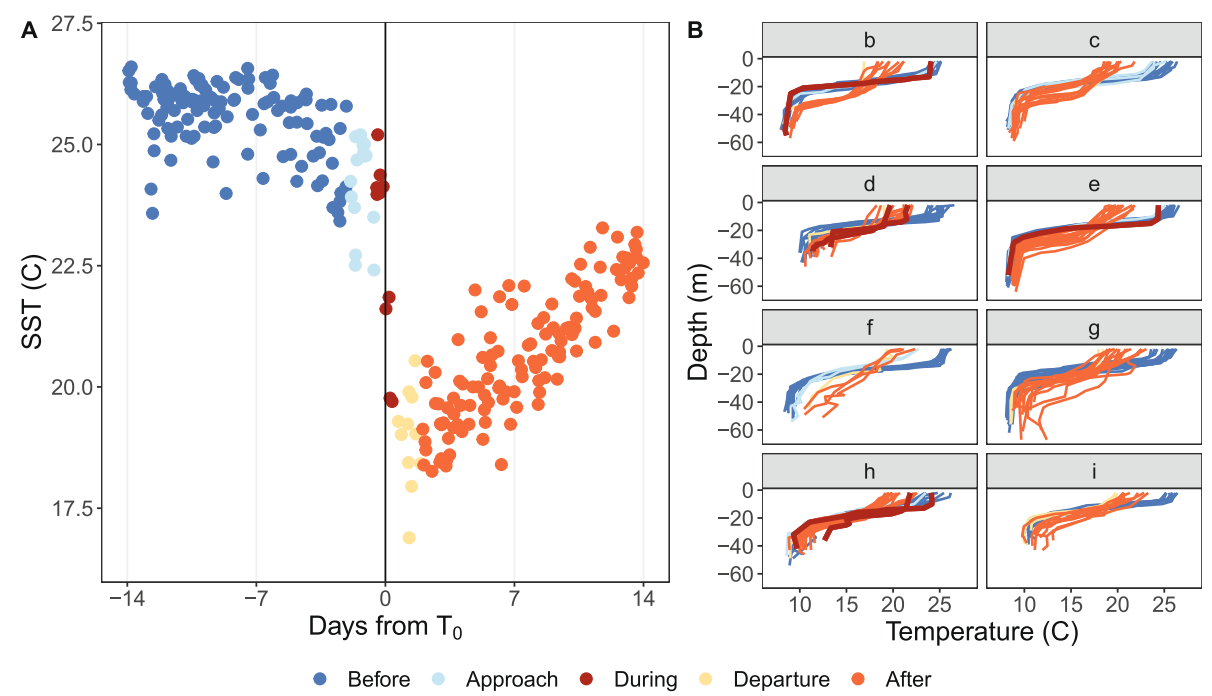

Fig. 5 In situ water temperature data collected from turtle-borne tags $b-i$. These turtles remained in their foraging areas in the After phase and were along a similar latitudinal range (between $37.68^{\circ} \mathrm{N}$ and $39.30^{\circ} \mathrm{N}$ ). a Sea surface temperature values collected at $2 \mathrm{~m}$ depth and $\mathbf{b}$ full water column (within 15\% of the bottom) temperature-depth profiles throughout all phases

Table 1 Deployment details, straight carapace length (SCL), measured from the nuchal notch to posterior marginal tip, and size class for each tagged turtle used in this analysis. Life stages III and IV are mid and later stage juveniles, respectively [49]

\begin{tabular}{|c|c|c|c|c|c|}
\hline \multirow[b]{2}{*}{ ID } & \multicolumn{3}{|c|}{ Deployment } & \multicolumn{2}{|c|}{ Size \& Age Class } \\
\hline & Date & Latitude $(\mathrm{N})$ & Longitude $(W)$ & $\mathrm{SCL}(\mathrm{cm})$ & Life Stage \\
\hline $\mathrm{a}$ & 04 Jun 2011 & 37.71 & -74.73 & 69.7 & IVa \\
\hline $\mathrm{b}$ & 06 Jun 2011 & 37.95 & -74.72 & 68.5 & III \\
\hline $\mathrm{c}$ & 06 Jun 2011 & 37.97 & -74.73 & 74.4 & IVa \\
\hline d & 06 Jun 2011 & 37.97 & -74.73 & 66.6 & III \\
\hline $\mathrm{e}$ & 06 Jun 2011 & 37.95 & -74.71 & 87.0 & $\mathrm{IVb}$ \\
\hline f & 03 Jun 2011 & 37.99 & -74.62 & 71.6 & IVa \\
\hline $\mathrm{g}$ & 03 Jun 2011 & 37.98 & -74.61 & 81.7 & $\mathrm{IVb}$ \\
\hline $\mathrm{h}$ & 03 Jun 2011 & 37.99 & -74.63 & 76.1 & IVa \\
\hline $\mathrm{i}$ & 06 Jun 2011 & 38.00 & -74.74 & 73.1 & IVa \\
\hline $\mathrm{j}$ & 03 Jun 2011 & 38.04 & -74.61 & 62.8 & III \\
\hline $\mathrm{k}$ & 06 Jun 2011 & 37.95 & -74.68 & 68.0 & III \\
\hline 1 & 26 Jul 2011 & 39.38 & -73.29 & - & III \\
\hline $\mathrm{m}$ & 04 Jun 2011 & 37.76 & -74.71 & 83.2 & $\mathrm{IVb}$ \\
\hline $\mathrm{n}$ & 02 Jun 2011 & 38.71 & -74.14 & 66.5 & III \\
\hline o & 06 Jun 2011 & 37.97 & -74.72 & 58.1 & III \\
\hline $\mathrm{p}$ & 03 Jun 2011 & 37.99 & -74.62 & 75.4 & IVa \\
\hline$q$ & 06 Jun 2011 & 37.94 & -74.70 & 73.2 & IVa \\
\hline $\mathrm{r}$ & 04 Jun 2011 & 37.73 & -74.71 & 84.6 & $\mathrm{IVb}$ \\
\hline
\end{tabular}


(turtle q) $-62.1 \mathrm{~km}$ (turtle $c$ ) between the median latitudes of the Before and During phases.

Despite some temporary northward movement During the hurricane, the interquartile range in the After phase was at least partially within the pre-storm foraging area for 10 turtles ( $a-j$; Fig. 3a, light green), and completely outside of it for eight turtles $(k-r$; Fig. 3a, darker green), which had mostly moved south. A comparison of median latitudes of the 10 turtles that remained in their foraging areas showed that all of them went north in the During phase and then came south in the After phase (Fig. 3a, e.g. Fig. 3b, turtle c). Two of the turtles that remained did not leave their foraging area in the During phase (e.g. Fig. 3b, turtle $i$ ). Of the eight turtles that went out of their foraging grounds after the hurricane, one of them went inshore (Fig. 3b, turtle $k$ ), and the rest went south, traveling $7.3-135.0 \mathrm{~km}$ between the southern limit of their pre-storm foraging site and the median latitude of the After phase (e.g. Fig. 3b, turtle $r$ ).

Dive duration and maximum dive depth changed as the hurricane passed the animals remaining in their foraging areas $(n=1185$ total dives, Fig. 4). Longer dive durations were observed in the During phase and continued into the Departure phase when the longest dive was observed $(1.70 \mathrm{~h})$. While dive duration shortened moving from the Departure to the After phase, they were still longer than dives in the Before and $A p$ proach phases. Before the passage of the hurricane, all but one dive was less than $0.54 \mathrm{~h}$. After the hurricane, approximately $12 \%$ of the dives, taken by nine of the 10 turtles, exceeded $0.54 \mathrm{~h}$, including a few that exceeded one hour ( $\mathrm{Max}=1.11 \mathrm{~h}$, Fig. 4). The Before and After phases had similar numbers of dives (Before: $n=381$; After: $n=366$ ), and the dive duration was longer (hours; Before: Mean $=0.19, \mathrm{SD}=0.13 ;$ After: Mean $=0.23, \mathrm{SD}=$ $0.24)$ and maximum dive depth was shallower $(\mathrm{m}$; Before: Mean $=26.33, \quad \mathrm{SD}=20.57 ;$ After $:$ Mean $=20.60, \quad \mathrm{SD}=$ 19.91) in the After phase. However, shallow and deep dives were observed throughout all phases of the hurricane (Fig. 4).

\section{Environmental data}

Turtles $b-i$ were considered good hurricane observers as these animals remained in their foraging grounds and were also within a similar latitudinal range (between $37.68^{\circ} \mathrm{N}$ and $\left.39.30^{\circ} \mathrm{N}\right)$. Data collected in this region $(n=$ 354) showed SST dropping at $T_{0}$ followed by a warming throughout the After phase (Fig. 5a). The number of SST data points collected in the Before and After phases were similar (Before: $n=249 ;$ After: $n=251$ ), and the SST was cooler in the After phase $\left({ }^{\circ} \mathrm{C}\right.$; Before: Mean $=$ 25.14, $\quad \mathrm{SD}=1.20 ; \quad$ After: $\quad$ Mean $=20.67, \quad \mathrm{SD}=1.36$ ). Additionally, temperature-depth profiles $(n=225)$ were compiled for these turtles relative to all five phases (Fig.
$5 \mathrm{~b})$. These profiles revealed changes in the thermocline relative to the passing of the hurricane, and for all turtles, deeper and cooler thermoclines were observed in the After phase.

$T_{0}$ for the weather buoy was also identified as 28 1August 2011. A decrease in barometric pressure and SST and an increase in wave height and wind speed after $T_{0}$ was recorded during this period (Fig. 2c) consistent with the passing of a Category 1 hurricane $[4,10]$.

The location, dive, and temperature-depth data generated and analyzed in this study are available in Additional file 3.

\section{Discussion}

Hurricane Irene tracked along a large portion of the United States eastern seaboard that is valued for recreation, shipping, fishing, seismic exploration, and wind farm development. It is also an important habitat for many protected species [50], and supports densely populated coastal communities [51]. Due to this confluence of potentially conflicting interactions between humans and protected species, this region is highly managed in order to reduce harmful anthropogenic impacts. As the region experiences a rising intensity in ecosystem perturbations, including hurricanes [3], effective management becomes harder as animals may become displaced in space and time.

Ecosystem-level perturbations can cause turtles to alter their routine behavior by direct effects or through habitat modifications. Here we show that sea turtle distribution and dive behavior change with an extreme weather event. Elsewhere, storm degraded habitats have possibly resulted in shifts in loggerhead foraging areas [52]. During a marine heatwave, loggerheads moved into shallower regions where the destruction of seagrass beds may have revealed short-term access to new benthic forage [53]. Anthropogenic perturbations can also illicit direct or indirect changes to sea turtle behavior. Multiple low-sample-size studies suggest the possibility that sound may trigger a response in turtles $[54,55]$. Dredge operations were associated with changes in flatback sea turtle (Natator depressus) distribution and dive behavior, possibly due to noise impacts and changes to the benthos [56]. Seismic activity, windfarm development, and marine recreation may impact sea turtle distribution and dive behavior directly or through habitat alterations [54, 57-59]. The longterm, cumulative impacts of climate and anthropogenic impacts on sea turtle behavior and distribution in the MAB warrant consideration [57, 60] and may have legacy effects [53] for sea turtle research and management.

\section{Behavior}

Loggerhead sea turtles overlap spatiotemporally with extreme weather events, and turtle dive behavior did not return to pre-storm behavior within at least two weeks 
following a storm. The latitudinal displacement and changes in loggerhead dive behavior are the consequences of either an acute perturbation, an alteration of larger scale oceanographic conditions, or both. The behavioral changes observed in this study are an opportunistic look at neritic turtle behavior relative to a hurricane, and it is currently unclear what aspect of the environment (i.e. sound from increased wind, shifts in barometric pressure, altered currents, lower SSTs, deepened thermocline, or disrupted prey fields) led to the observed behavior.

The turtles that left their foraging ranges moved south earlier than would be expected from normal patterns of seasonal movement, and earlier than the seasonal water column cooling $[7,8,26]$. Hurricane Irene passed through the MAB at the end of August 2011 when there was still more than a month of the foraging season remaining [26] (Supplementary Fig. 2 Additional file 1), and more than a month before the Cold Pool normally dissipates due to the autumn turnover [7, 8]. Despite this, nearly half of the turtles in this study vacated their pre-storm foraging areas and moved south by as far as $135 \mathrm{~km}$ after the hurricanea distance that is nearly $25 \%$ of a typical southward migration to the coastal waters of North Carolina [26]. While in the MAB, loggerheads usually exhibit seasonal home range fidelity and occupy a SST thermal range between $18.2^{\circ}-29.2^{\circ} \mathrm{C}$ [28]. Although the water temperatures quickly cooled due to the storm, the turtles that remained in their pre-storm foraging ranges did not experience SSTs outside of typically occupied temperatures (Fig. 5).

Turtles that stayed in their foraging ranges took longer dives after the hurricane. The difference in mean dive duration before and after the hurricane may not be biologically significant, but the increased range suggests that the storm, and its impacts on the water column, may have had an effect. The changes in dive duration observed with the passing of the hurricane are similar to behavior changes observed with seasonal decreases in SST [61]. Loggerhead behavior is likely sensitive to these changes in thermal conditions, as research has identified that a $2^{\circ} \mathrm{C}$ difference in SST can alter dive behavior $[62,63]$. These changes in dive behavior could have been triggered by the transformation of the entire water column, including the decrease in SST [64], disruption of the thermocline, and the weakening of the overall stratification [65].

The northward movements for most of the turtles during the hurricane aligned with the direction of the dominant along-shelf surface current associated with the storm's passing [10]. In the $12 \mathrm{~h}$ after the eye of Irene passed the MAB, the current velocity at up to $20 \mathrm{~m}$ depth was $0.4-0.8 \mathrm{~m} \mathrm{~s}^{-1}$ moving northward [10]. The horizontal movement of loggerhead sea turtles in all life stages are influenced by surface currents, either by physical mechanisms $[66,67]$ or by learned experiences [68].
Smaller turtles that swim slower than currents are able to influence their overall trajectory and survival success by purposeful alignment and short periods of active swimming [67, 69-71]. Juvenile loggerheads are capable of escaping current patterns $[69,72]$, but powerful currents can alter the course of even a strong, adult turtle [73]. The movement north of most of the turtles in this study during the hurricane could possibly be a tactic to conserve energy by purposeful alignment [69, 72, 74].

A shift in sea turtle distribution and diving behavior can influence the calculations used in creating abundance estimates from aerial surveys, and abundance estimates that assume constant sea turtle behavior through time may appear more accurate than they are $[38,75]$. As other studies have reported, neglecting the variability of environmentally influenced dive behavior can have substantial effects on density estimates [75]. Analysis of visual survey data collected after extreme weather events or other perturbations should consider that turtles may be triggered to leave an area and/or alter their dive patterns.

\section{Animal-borne \& weather buoy in-situ environmental observations}

Tagged turtles that remained in their foraging regions during Hurricane Irene effectively recorded the SST drop as well as the vertical mixing of the stratified MAB. The water temperature data from the turtle tags were consistent with weather buoy and glider observations during this period, but more spatially extensive than other oceanographic data sources [10]. Stratified environments are challenging to model, and more data from in situ sources are needed and being sought to improve hurricane forecasting in these types of regions $[9,11]$. The ahead-of-eye cooling is a characteristic of Atlantic hurricanes that come through the MAB during the stratified summer period [10], and this aspect has proven to be a major limiting factor to accurately model storms as well as prepare regions for hurricane damage. We show in this study that turtleborne tags collect additional in situ data on the MAB during a time of year that is the perfect storm of turtle foraging season, stratification and formation of the Cold Pool, as well as the Atlantic hurricane season.

\section{Conclusions}

Consistent with Patel et al. [11], turtle-borne data can provide in situ oceanography data in the seasonally stratified MAB as loggerhead sea turtles observe the entire water column profile, including during extreme weather events. This study gave one example of how loggerhead behavior and distribution changed during an ecosystem perturbation, suggesting that we cannot assume consistency through time. Future analysis of turtle behavior should consider the dynamic environments in which they live. 


\section{Supplementary information}

Supplementary information accompanies this paper at https://doi.org/10. 1186/s40462-020-00218-6.

Additional file 1. Location source for tagged turtles and previously observed proportions of tagged turtles in the Mid-Atlantic Bight by month.

Additional file 2. Interactive map of turtle tracks before, during, and after Hurricane Irene.

Additional file 3. Location source for tagged turtles and previously observed proportions of tagged turtles in the Mid-Atlantic Bight by month.

\section{Abbreviations}

cm: Centimeter; EDT: Eastern Daylight Time; Fig.: Figure; GPS: Global positioning system; h: Hour; km: Kilometers; m: Meters; MAB: Mid-Atlantic Bight; ${ }^{\circ} \mathrm{N}$ : Degrees North; $n$ : Sample size; SCL: Straight carapace length; SD: Standard deviation; SST: Sea Surface Temperature; $T_{0}$ : Time when the turtle is at its closest point to Hurricane Irene; USD: United States Dollars; 'W: Degrees West; degrees C: Degrees; Celsius: Seconds

\section{Acknowledgements}

Thank you to the captains and crew at Viking Village Fisheries, and to the scientists on the cruises, particularly Eric Matzen. Thank you to Sean Hayes, Mike Simpkins, and anonymous reviewers for their helpful comments that improved the manuscript.

\section{Authors' contributions}

$\mathrm{HLH}$ and RJS collected the data. SHP conceived of the original idea. JMH, LMC, and SHP performed the data analysis. HLH, LMC, and SHP created the figures. LMC wrote the initial draft of the manuscript in consultation with $\mathrm{HLH}$. All authors contributed to the design of the study, the interpretation of the data, the final version of the manuscript, and approved the final manuscript.

\section{Funding}

Turtle satellite tagging was made possible by funding from the Sea Scallop Research Set Aside program (NA11NMF4540024) and by a US Department of Interior, Bureau of Ocean Energy Management Inter-Agency Agreement (M10PG00075)

\section{Availability of data and materials}

Data generated and analyzed during this study are included in this published article [Additional file 3].

\section{Ethics approval and consent to participate}

This study meets the legal requirements of capturing, handling, and attaching satellite tags to loggerhead sea turtles in the United States under Endangered Species Act Permits \#1551 issued to the Southeast Fisheries Science Center, \#1576 issued to the Northeast Fisheries Science Center, and \#14249 issued to the Coonamessett Farm Foundation.

\section{Consent for publication}

Not applicable.

\section{Competing interests}

The author(s) declare(s) that they have no competing interests.

\section{Author details}

${ }^{1}$ Integrated Statistics under contract to the Northeast Fisheries Science Center, National Marine Fisheries Service, National Oceanic and Atmospheric Administration, 166 Water Street, Woods Hole, MA 02543, USA. ${ }^{2}$ Northeast Fisheries Science Center, National Marine Fisheries Service, National Oceanic and Atmospheric Administration, 166 Water Street, Woods Hole, MA 02543, USA. ${ }^{3}$ Coonamessett Farm Foundation, 277 Hatchville Road, East Falmouth, MA 02536, USA
Received: 3 April 2020 Accepted: 3 July 2020

Published online: 27 July 2020

\section{References}

1. Easterling DR, Meehl GA, Parmesan C, Changnon SA, Karl TR, Mearns LO. Climate extremes: observations, modeling, and impacts. Science. 2000;289(5487):2068-74. https://doi.org/10.1126/science.289.5487. 2068 .

2. Peduzzi P, Chatenoux B, Dao H, De Bono A, Herold C, Kossin J, et al. Global trends in tropical cyclone risk. Nat Clim Chang. 2012;2:289-94.

3. Kossin JP, Knapp KR, Olander TL, Velden CS. Global increase in major tropical cyclone exceedance probability over the past four decades. Proc Natl Acad Sci U S A. 2020. https://doi.org/10.1073/pnas. 1920849117.

4. Avila LA, Cangialosi J. Tropical cyclone report, Hurricane Irene (AL092011), 21-28 August 2011. 2011. Available from: https://www.nhc.noaa.gov/data/ tcr/AL092011_Irene.pdf. [cited 16 Dec 2016].

5. Cox SL, Embling CB, Hosegood PJ, Votier SC, Ingram SN. Oceanographic drivers of marine mammal and seabird habitat-use across shelf-seas: a guide to key features and recommendations for future research and conservation management. Estuar Coast Shelf Sci. 2018;212:294-310. https://doi.org/10. 1016/j.ecss.2018.06.022.

6. Saba VS, Griffies SM, Anderson WG, Winton M, Alexander MA, Delworth TL, et al. Enhanced warming of the Northwest Atlantic Ocean under climate change. J Geophys Res Oceans. 2016;121:118-32.

7. Lentz SJ. Seasonal warming of the Middle Atlantic Bight Cold pool. J Geophys Res Oceans. 2017;122:941-54. https://doi.org/10.1002/ 2016JC012201.

8. Patel SH, Barco SG, Crowe LM, Manning JP, Matzen E, Smolowitz RJ, et al. Loggerhead turtles are good ocean-observers in stratified mid-latitude regions. Estuar Coast Shelf Sci. 2018;213:128-35. https://doi.org/10.1016/j. ecss.2018.08.019.

9. Testor P, de Young B, Rudnick DL, Glenn S, Hayes D, Lee CM, et al. OceanGliders: a component of the integrated GOOS. Front Mar Sci. 2019;6: 422. https://doi.org/10.3389/fmars.2019.00422

10. Glenn SM, Miles TN, Seroka GN, Xu Y, Forney RK, Roarty H, et al. Stratified coastal ocean interactions with tropical cyclones. Nat Commun. 2016;7: 10887. https://doi.org/10.1038/ncomms10887.

11. Seroka G, Miles T, Xu Y, Kohut J, Schofield O, Glenn S. Hurricane Irene sensitivity to stratified coastal ocean cooling. Mon Weather Rev. 2016;144: 3507-30. https://doi.org/10.1175/MWR-D-15-0452.1.

12. Jury $\mathrm{SH}$, Howell WH, Watson WH. Lobster movements in response to a hurricane. Mar Ecol Prog Ser. 1991;119:305-10.

13. Heupel MR, Simpfendorder CA, Hueter RE. Running before the storm: blacktip sharks respond to falling barometric pressure associated with Tropical Storm Gabrielle. J Fish Biol. 2003;63:1357-63. https://doi.org/10. 1046/j.1095-8649.2003.00250.x.

14. Liu YL, Lillywhite HB, Tu MC. Sea snakes anticipate tropical cyclone. Mar Biol. 2010;157:2369-73. https://doi.org/10.1007/s00227-010-1501-x.

15. Udyawer V, Chin A, Knip DM, Simpfendorfer CA, Heupel MR. Variable response of coastal sharks to severe tropical storms: environmental cues and changes in space use. Mar Ecol Prog Ser. 2013;480:171-83. https://doi. org/10.3354/meps10244.

16. Bachelor NM, Shertzer KW, Cheshire RT, MacMahan JH. Tropical storms influence the movement behavior of a demersal oceanic fish species. Sci Rep. 2019:9(1):1481. https://doi.org/10.1038/s41598-018-37527-1.

17. Biggs CR, Lowerre-Barbieri SK, Erisman B. Reproductive resilience of an estuarine fish in the eye of a hurricane. Biol Lett. 2018;14:20180579. https:// doi.org/10.1098/rsbl.2018.0579

18. Wilkinson BP, Satgé YG, Lamb JS, Jodice PGR. Tropical cyclones alter shortterm activity patterns of a coastal seabird. Mov Ecol. 2019;4:30. https://doi. org/10.1186/s40462-019-0178-0.

19. Storch S, Hays GC, Hillis-Starr Z, Wilson RP. The behavior of a hawksbill turtle data-logged during the passage of hurricane Georges through the Caribbean. Mar Freshw Behav Physiol. 2006;39(4):307-13. https://doi.org/10. 1080/10236240600919796

20. Wilson M, Tucker AD, Beedholm K, Mann DA. Changes of loggerhead turtle (Caretta caretta) dive behavior associated with tropical storm passage during the inter-nesting period. J Exp Biol. 2017:220:3432-41. https://doi. org/10.1242/jeb.162644. 
21. Dodd CK, Byles R. Post-nesting movements and behavior of loggerhead sea turtles (Caretta caretta) departing from East-Central Florida nesting beaches. Chelonian Conserv Biol. 2003;4(3):530-6.

22. Schofield G, Hobson VJ, Lilley MKS, Katselidis KA, Bishop CM, Brown P, et al. Inter-annual variability in the home range of breeding turtles: implications for current and future conservation management. Biol Conserv. 2010;143: 722-30. https://doi.org/10.1016/j.biocon.2009.12.011.

23. Matley JK, Eanes S, Nemeth RS, Jobsis PD. Vulnerability of sea turtles and fished in response to two catastrophic Caribbean hurricanes, Irma and Maria. Sci Rep. 2019;9:14254. https://doi.org/10.1038/s41598-01950523-3.

24. DuBois MJ, Putnam NF, Piacenza SE. Hurricane frequency and intensity may decrease dispersal of Kemp's ridley sea turtle hatchlings in the Gulf of Mexico. Front Mar Sci. 2020;7:301. https://doi.org/10.3389/fmars.2020.00301.

25. Monzón-Argüello C, Dell'Amico F, Morinière, Marco A, López-Jurado LF, Hays GC, et al. Lost at sea: genetic, oceanographic and meteorological evidence for storm-forced dispersal. J R Soc Interface. 2011. https://doi.org/ 10.1098/rsif.2011.0788.

26. Winton MV, Fay G, Haas HL, Arendt M, Barco S, James MC, et al. Estimating the distribution and relative density of satellite-tagged loggerhead sea turtles using geostatistical mixed effects models. Mar Ecol Prog Ser. 2018; 586:217-32. https://doi.org/10.3354/meps12396.

27. Hurricane Research Division. Tropical cyclone FAQ: when is hurricane season? 2015. Available from: http://www.aoml.noaa.gov/hrd/tcfaq/G1.html. [Accessed 31 Oct 2019].

28. Hawkes LA, Witt MJ, Broderick AC, Coker JW, Coyne MS, Dodd M, et al. Home on the range:spatial ecology of loggerhead turtles in Atlantic waters of the USA. Divers Distrib. 2011;17:624-40. https://doi.org/10.1111/j.14724642.2011.00768.x

29. Doi T, Storto A, Fukuoka T, Suganuma H, Sato K. Impacts of temperature measurements from sea turtles on seasonal prediction around the Arafura Sea. Front Mar Sci. 2019;6:719. https://doi.org/10. 3389/fmars.2019.00719.

30. Fedak M, Lovell P, McConnell B, Hunter C. Overcoming the constraints of long range radio telemetry from animals: getting more useful data from small packages. Integr Comp Biol. 2002;43:3-10. https://doi.org/10.1093/icb/42.1.3.

31. Dujon AM, Lindstrom RT, Hays GC. The accuracy of Fastloc-GPS locations and implications for animal tracking. Methods Ecol Evol. 2014:5:1162-9. https://doi.org/10.1111/2041-210X.12286.

32. Douglas DC, Weinzierl R, Davidson SC, Kays R, Wikelski M, Bohrer G. Moderating Argos location errors in animal tracking data. Methods Ecol Evol. 2012;3:999-1007. https://doi.org/10.1111/j.2041-210X.2012.00245.x.

33. Thomson JA, Börger L, Christianen MJA, Esteban N, Laloë J-O. Implications of location accuracy and data volume for home range estimation and finescale movement analysis: comparing Argos and Fastloc-GPS tracking data. Mar Biol. 2017;164:204. https://doi.org/10.1007/s00227-017-3225-7.

34. R Core Team. R: A language and environment for statistical computing. Vienna: R Foundation for Statistical Computing; 2018. Available from: https://www.R-project.org/. [cited 31 Oct 2019].

35. Wickham H, Romain F, Lionel H, Müller K. dplyr: a grammar of data manipulation. 2018. R package version 0.7.7. Available from: https://CRAN.Rproject.org/package $=$ dplyr [cited 31 Oct 2019].

36. Hijmans RJ. Geosphere: spherical trigonometry. 2019. R package version 1.510. https://CRAN.R-project.org/package=geosphere. [cited 15 May 2020].

37. Garrett G, Wickham H. Dates and times made easy with lubridate. J Stat Softw. 2011;40(3):1-25 Available from: http://www.jstatsoft.org/v40/i03/. [cited 31 Oct 2019].

38. Wickham H. The split-apply-combine strategy for data analysis. J Stat Softw. 2011;40(1):1-29 Available from: http://www.jstatsoft.org/v40/i01/. [cited 31 Oct 2019].

39. National Hurricane Center GIS Archive - Tropical cyclone best track. https:// www.nhc.noaa.gov/gis/archive_besttrack_results.php?id=al09\&year=201 \&name=Hurricane\%20IRENE. Accessed 15 May 2020.

40. Barco SG, Burt ML, DiGiovanni RA, Swingle M, Willard AS. Loggerhead turtle Caretta caretta density and abundance in Chesapeake Bay and the temperate ocean waters of the southern portion of the Mid-Atlantic Bight. Endanger Species Res. 2018;37:269-87. https://doi.org/10.3354/esr00917.

41. Amante C, Eakins BW. ETOPO1 1 Arc-minute global relief model: procedures, data sources and analysis. NOAA Technical Memorandum NESD IS NGDC-24, 19 pp, March 2009. Available from: http://www.ngdc.noaa.gov/ mgg/global/global.html. [cited 21 Feb 2019].
42. Hijmans RJ. raster: geographic data analysis and modeling. 2018. R package version 2.8-4. Available from: https://CRAN.R-project.org/package=raster. [cited 31 Oct 2019].

43. Bivand R, Keitt T, Rowlingson B. rgdal: bindings for the 'geospatial' data abstraction library. 2018. R package version 1.3-6. Available from: https:// CRAN.R-project.org/package=rgdal. [cited 31 Oct 2019].

44. ESRI. ArcGIS desktop: release 10. Redlands: Environmental Systems Research Institute; 2011.

45. National Data Buoy Center. https://www.ndbc.noaa.gov/station_page. php?station=44009. Accessed 26 Sep 2019.

46. Wickham H. ggplot2: elegant graphics for data analysis. New York: SpringerVerlag; 2016. ISBN 978-3-319-24277-4. Available from: https://ggplot2. tidyverse.org. [cited 31 Oct 2019].

47. Alboukadel K. ggpubr:'ggplot2' based publication ready plots. 2018. R package version 0.1.9. Available from: https://CRAN.R-project.org/package= ggpubr. [cited 31 Oct 2019].

48. Avens L, Goshe LR, Coggins L, Snover ML, Pajuelo M, Bjorndal KA, et al. Age and size at maturation- and adult-stage duration for loggerhead sea turtles in the western North Atlantic. Mar Biol. 2015;162(9):1749-67. https://doi.org/ 10.1007/s00227-015-2705-x.

49. Murray KT. Interactions between sea turtles and dredge gear in the U.S. sea scallop (Placopecten magellanicus) fishery, 2001-2008. Fish Res. 2011;107: 137-46. https://doi.org/10.1016/j.fishres.2010.10.017.

50. Avila IC, Kaschner K, Dormann CF. Current global risks to marine mammals: taking stock of the threats. Biol Conserv. 2018;221:44-58. https://doi.org/10. 1016/j.biocon.2018.02.021.

51. Prasad S. An assessment of human vulnerability to hazards in the US coastal Northeast and mid-Atlantic. Southeast Geogr. 2012;52(3):282-98.

52. Shimada T, Limpus CJ, Hamann M, Bell I, Esteban N, Groom R, et al. Fidelity to foraging sites after long migrations. J Anim Ecol. 2019;89:1008-16. https://doi.org/10.1111/1365-2656.13157.

53. Nowicki R, Heithaus M, Thomson J, Burkholder D, Gastrich K, Wirsing A. Indirect legacy effects of an extreme climatic event on a marine megafaunal community. Ecol Monogr. 2019:89:e01365.

54. Nelms SE, Piniak WED, Weir CR, Godley BJ. Seismic surveys and marine turtles: an underestimated global threat? Biol Conserv. 2016;193:49-65. https://doi.org/10.1016/j.biocon.2015.10.020.

55. Tyson RB, Piniak WED, Domit C, Mann D, Hall M, Nowacek DP, et al. Novel bio-logging tool for studying fine-scale behaviors of marine turtles in response to sound. Front Mar Sci. 2017;4:219. https://doi.org/10.3389/fmars. 2017.00219.

56. Whittock PA, Pendoley KL, Larsen R, Hamann M. Effects of a dredging operation on the movement and dive behaviour of marine turtles during breeding. Biol Conserv. 2017;2016:190-200. https://doi.org/10.1016/j.biocon. 2016.12.015.

57. Kraus SD, Kenney RD, Thomas L. A framework for studying the effects of offshore wind development on marine mammals and turtles. Report prepared for the Massachusetts Clean Energy Center, Boston, MA 02110, and the Bureau of Ocean Energy Management. May, 2019.

58. Samuel Y, Morreale SJ, Clark CW, Greene CH, Richmond ME. Underwater, low-frequency noise in a coastal sea turtle habitat. J Acoust Soc Am. 2005; 117(3):1465-72. https://doi.org/10.1121/1.1847993.

59. Carpenter JR, Merckelbach L, Callies U, Clark S, Gaslikova L, Baschek B. Potential impacts of offshore wind farms on North Sea Stratification. PLoS One. 2016;11(8):e0160830. https://doi.org/10.1371/journal.pone.0160830.

60. Wright AJ, Araujo-Wang C, Wang JY, Ross PS, Tougaard J, Winkler R, et al. How 'blue' is 'green' energy? Trends Ecol Evol. 2019. https://doi.org/10.1016/ j.tree.2019.11.002.

61. Hochscheid S, Bentivegna F, Hays GC. First record of dive durations for a hivernating sea turtle. Biol Lett. 2005;1:82-6. https://doi.org/10.1098/rsbl. 2004.0250.

62. Godley BJ, Broderick AC, Glen F, Hays GC. Post-nesting movements and submergence patterns of loggerhead marine turtles in the Mediterranean assessed by satellite telemetry. J Exp Mar Biol Ecol. 2003; 281:119-34

63. Patel SH, Morreale SJ, Panagopoulou A, Bailey H, Robinson NJ, Paladino FV, et al. Changepoint analysis: a new approach for revealing animal movements and behaviors from satellite telemetry data. Ecosphere. 2015; 6(12):291

64. Mansfield KL, Saba VS, Keinath JA, Musick JA. Satellite tracking reveals a dichotomy in migration strategies among juvenile loggerhead turtles in the 
Northwest Atlantic. Mar Biol. 2009;156:2555-70. https://doi.org/10.1007/ s00227-009-1279-X.

65. Howell EA, Dutton PH, Polovina JJ, Bailey H, Parker DM, Balazs GH. Oceanographic influences on the dive behavior of juvenile loggerhead turtles (Caretta caretta) in the North Pacific Ocean. Mar Biol. 2010;157:1011-26. https:// doi.org/10.1007/s00227-009-1381-0.

66. Putman NF, Verley P, Shay TJ, Lohmann KJ. Simulating transoceanic migrations of young loggerhead sea turtles: merging magnetic navigation behavior with an ocean circulation model. J Exp Biol. 2012;215:1863-70. https://doi.org/10.1242/jeb.067587.

67. Scott R, Marsh R, Hays GC. Life in the really slow lane: loggerhead sea turtles mature late relative to other reptiles. Funct Ecol. 2012;26:227-35. https://doi. org/10.1111/j.365-2435.2011.01915.x

68. Scott R, Marsh R, Hays GC. Ontogeny of long distance migration. Ecology. 2014:95(10):2840-50.

69. Christiansen F, Putman NF, Farman R, Parker DM, Rice MR, Polovina JJ, et al. Spatial variation in directional swimming enables juvenile sea turtles to reach and remain in productive waters. Mar Ecol Prog Ser. 2016;557:247-59. https://doi.org/10.3354/maps11874.

70. Mansfield KL, Mendilaharsu ML, Putman NF, dei Marcovaldi MAG, Sacco AE, Lopez G, et al. First satellite tracks of South Atlantic sea turtle 'lost years': seasonal variation in trans-equatorial movement. Proc R Soc B Biol Sci. 2017; 284:20171730. https://doi.org/10.1098/rspb.2017.1730.

71. Putnam NF, Scott R, Verley R, Marsh R, Hays GC. Natal site and offshore swimming influence fitness and long-distance ocean transport in young sea turtles. Mar Biol. 2012:159:2117-26. https://doi.org/10.1007/s00227-012-1995-5.

72. Cardona L, Hays GC. Ocean currents, individual movements and genetic structuring of populations. Mar Biol. 2018;165:10. https://doi.org/10.10007/ s00227-017-3262-2.

73. Hays GC. Ocean currents and marine life. Curr Biol. 2017;27:R470-3. https:// doi.org/10.1016/j.cub.2017.01.044

74. Luschi P, Hays GC, Papi F. A review of long-distance movements by marine turtles, and the possible role of ocean currents. Oikos. 2003;103:293-302.

75. Thomson JA, Cooper AB, Burkholder DA, Heithaus MR, Dill LM. Correcting for heterogeneous availability bias in surveys of long-diving marine turtles. Biol Conserv. 2013;165:154-61. https://doi.org/10.1016/j.biocon.2013.06.005.

\section{Publisher's Note}

Springer Nature remains neutral with regard to jurisdictional claims in published maps and institutional affiliations.

Ready to submit your research? Choose BMC and benefit from:

- fast, convenient online submission

- thorough peer review by experienced researchers in your field

- rapid publication on acceptance

- support for research data, including large and complex data types

- gold Open Access which fosters wider collaboration and increased citations

- maximum visibility for your research: over $100 \mathrm{M}$ website views per year

At $\mathrm{BMC}$, research is always in progress.

Learn more biomedcentral.com/submissions 